\title{
Estimasi Usia Anak Etnis Tionghoa di Indonesia dengan Menggunakan Metode Willems
}

\author{
Shintya Rizki Ayu Agitha*1, Mieke Sylvia M.A.R ${ }^{2}$, Haryono Utomo ${ }^{3}$ \\ ${ }^{1,2}$ Sekolah Pascasarjana; Kampus B Jl.Airlangga no 4-6 Surabaya,031-5041566 \\ ${ }^{3}$ Departemen Odontologi Forensik, FKG UNAIR, Surabaya

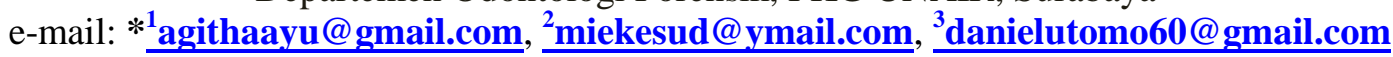

\begin{abstract}
Abstrak
Estimasi usia merupakan bagian dari ilmu forensic dan merupakan bagian penting dalam setiap proses identifikasi. Maturasi gigi penting dalam estimasi usia kronologis seseorang. beberapa metode dapat digunakan untuk estimasi usia pada anak. Metode Willems merupakan modifikasi dari metode Demirjian yang menggunakan kalsifikasi mahkota dan akar gigi untuk estimasi usia pada anak. Tujua penelitian ini adalah untuk mengetahui bahwa metode Willems dapat digunakan estimasi usia anak Tionghoa di Surabaya. Sebanyak 76 orthopantomogram yang terdiri dari 32 sampel anak laki-laki dan 44 sampel anak perempuan etni Tionghoa usia antara 6 - 13 tahun telah dianalisa. Metode Willems mengestimasi usia dental melalui penilaiaan terhadap tujuh gigi rahang bawah kiri. Usia kronologis diperoleh dari tanggal lahir anak tersebut.Perbedaan antara usia kronologis dan usia dental dianalisa menggunakan Uji Paired T Test. . Hasil penelitian ini menunjukkan pada laki - laki nilai $p=0,126 \quad(p>0.05)$, pada perempuan nilai $p=0,053$ ( $p>0.05$ ) dan pada keseluruhan sampel laki-laki dan perempuan nilai $p=0.843(p>0.05)$, hal ini berarti bahwa tidak ada perbedaan signifikan antara usia dental dan usia kronologis. Kesimpulan dari penelitian ini metode Willems dapat digunakan untuk estimasi usia anak etnis Tionghoa di Surabaya.
\end{abstract}

Kata kunci: estimasi usia, metode Willems, etnis Tionghoa,Surabaya

\begin{abstract}
Age estimation is a sub-disiplicine of the forensic science and should be an important part of every identification process. Dental maturity has played an important role in estimating the chronological age of individuals. Several approaches have proven be valuable in estimating dental age in children. The Willems is modification of the Demirjian method which based on crown and root calcification. This study aim to aplly Willems method in a Chinnese population in Surabaya for age estimation. A total of 76 panoramics radiographs from 32 boys and 44 girls Chinnese aged between 6 until 13 years were analyzed. The seven left mandibular teeth were scored and calculated in order to obtain the Willems estimated dental ages. Chronological age was obtained from the date of birth of children children. Difference between dental age and chronological age was analysed using paired t test. Based on comparison test, the result of this study showed on boys discrepancy of chronological age with dental age $p=0,126$ ( $p>0.05)$ and girls $p=0,053(p>0.05)$, in population boys and girls $p=0.843(p>0.05)$, it means no significant difference between dental age and chonological age. The conclusion of this research was Willems methode can be applied to Chinese children population in Surabaya for age estimation.
\end{abstract}

Keywords - age estimation, Wilems methode, chinese children population, Surabaya 


\section{PENDAHULUAN}

Indonesia merupakan negara kepulauan yang terdiri dari 13.667 pulau dengan batas luasnya sebesar $2.027 .087 \mathrm{~km}^{2}$ mempunyai kurang lebih 129 gunung merapi. Secara geologis Indonesia terletak di pertemuan di antara 3 plat tektonik utama (Eurasia, IndoAustralia dan Mediterania) dan secara demografi terdiri dari bermacam-macam etnik, agama, latar belakang sosial dan budaya, dimana keadaan tersebut memberikan petunjuk bahwa Indonesia berisiko tinggi sebagai negara yang rawan dari bencana alam terjadinya gempa bumi, Tsunami, longsor, banjir maupun kecelakaan baik darat, laut maupun udara (Singh S, 2008).

Berbagai kejadian yang memakan banyak korban jiwa, terutama sejak kejadian Bom Bali I membuat kegiatan identifikasi korban bencana massal (Disaster Victim Identification) menjadi kegiatan yang penting dan dilaksanakan hampir pada setiap kejadian yang menimbulkan korban jiwa dalam jumlah yang banyak. Tujuan utama pemeriksaan identifikasi pada kasus musibah bencana massal adalah untuk mengenali korban. Dengan identifikasi yang tepat selanjutnya dapat dilakukan upaya merawat, mendoakan serta akhirnya menyerahkan kepada keluarganya (Prawestiningtyas E, dkk, 2009).

Dalam kasus bencana massal, estimasi usia dapat menjadikan identifikasi korban lebih sederhana dengan mengelompokkan usia korban. Kasus hukum pidana atau perdata yang memerlukan estimasi usia pada individu hidup, antara lain kasus pemalsuan usia ketenagakerjaan, pernikahan, atlet, perwalian anak, keimigrasian,atau pemerkosaan. Pembuktian hukum tentang usia penting untuk menentukan individu tersebut masih dalam kategori anak atau sudah dewasa, berkaitan dengan adanya perbedaan proses hukum atau peradilan pada anak dengan orang dewasa. Estimasi usia juga merupakan pembuktikan yang berharga ketika akta kelahiran tidak ada atau diragukan keasliannya. Bagian tubuh yang umumnya dipakai untuk estimasi usia adalah skeletal dan gigi. Kematangan skeletal sebagai media estimasi usia memiliki keterbatasan karena hanya dapat mengestimasi usia pada rentang usia tertentu dengan simpangan baku usia yang besar sedangkan gigi sebagai media estimasi usia memiliki beberapa keunggulan, salah satunya adalah dapat mengestimasi usia pada individu dari usia prenatal sampai usia dewasa (Putri A.S, dkk, 2013).

Gigi mengalami tahap pertumbuhan dan perkembangan, serta perubahan degeneratif yang terjadi pada usia tertentu, sehingga dapat digunakan sebagai indikator estimasi usia individu dari sejak usia intrauterine sampai usia dewasa. Tahap pertumbuhan dan perkembangan gigi sebagai indikator estimasi usia lebih dikendalikan oleh faktor genetik dibandingkan dengan faktor lingkungan seperti nutrisi dan sosioekonomi sehingga usia dental menunjukkan variasi yang lebih sedikit dibandingkan dengan tulang atau bagian tubuh lain. Selain itu, gigi merupakan struktur tubuh yang paling keras dan resisten terhadap pengaruh eksternal, serta mengalami perubahan biologis yang paling sedikit sehingga dapat digunakan walaupun tubuh telah mengalami dekomposisi, mutilasi, terbakar, ataupun menjadi sisa rangka. Gigi dapat menyediakan informasi mengenai identitas seorang individu karena cirinya yang khas. Terdapat beberapa metode digunakan untuk menentukan usia dari gigi yaitu metode klinis, radiografis, histologis, dan biokimiawi. Pemilihan metode tersebut berdasarkan pertimbangan status individu (hidup atau mati), kategori usia, jenis kasus (tunggal atau bencana massal), kondisi gigi dan jaringan pendukung, lokasi kasus, ketersediaan fasilitas dan peralatan penunjang, serta agama dan budaya yang dianut individu tersebut (Putri A.S, dkk, 2013).

Metode estimasi usia kronologis pada anak berdasarkan tahap pertumbuhan dan perkembangan gigi dapat dilakukan dengan dua metode, antara lain berdasarkan skema perkembangan gigi yang telah ada dan berdasarkan sistem penilaian tahapan perkembangan gigi (Willems, 2001). Metode Demirjian sangat sering digunakan untuk menilai maturitas gigi dan memperkirakan usia kronologis anak (Willems et al, 2001). Pada tahun 2001, Willems merevisi sistem penilaian metode Demirjian karena berdasarkan dari beberapa penelitian yang ditemukan dari metode Demirjian hasilnya mengalami perbedaan usia dental yang tinggi dari usia kronologis anak. Oleh karena itu, Willems merevisi sistem penilaian yang dapat langsung mengekspresikan usia kronologis anak dan mempunyai akurasi yang lebih tinggi daripada metode Demirjian.

Metode Willems didasarkan pada tahap kalsifikasi pada mahkota gigi dan kalsifikasi pada akar yang berkaitan dengan penutupan apeks pada tujuh gigi permanen rahang bawah kiri. Tahap 
kalsifikasi dibagi dari $\mathrm{A}-\mathrm{H}$ dan setiap tahapan memiliki skor tersendiri. Jumlah skor dari tujuh gigi tersebut adalah usia dental yang merupakan estimasi usia kronologis anak (Willems, 2001). Menurut Willems, mungkin metodenya tersebut belum dapat menghasilkan estimasi usia kronologis anak yang akurat pada populasi lain, tetapi penelitian Ye X et al pada tahun 2014 menyatakan bahwa metode Willem menunjukkan hasil yang akurat pada populasi anak-anak Tionghoa dengan rata-rata perbedaan usia kronologis dan usia dental pada anak laki-laki 0,36 serta pada anak perempuan -0,02 ( Willems et al,2001; Ye X et al, 2014 ).

Orang Tionghoa sudah mengenal Nusantara sejak abad ke 5 masehi. Selama beberapa abad orang-orang Tionghoa terus bertambah jumlahnya tapi tidak ada catatan yang jelas jumlahnya diseluruh Nusantara. Catatan tentang angka didapat dari cacah jiwa yang diadakan pada masa pemerintahan Inggris di Jawa (tahun1811-1816). Dari buku "History of Java" karya Rafles tercatat bahwa orang Tionghoa sudah banyak yang menyebar ke pedalaman Jawa. Jumlahnya pada tahun 1815 di Jawa ada 94.441 orang sedangkan penduduk Jawa secara keseluruhan waktu itu berjumlah 4.615.270, berarti 2,04\% dari jumlah penduduk secara keseluruhan. Sebagian besar penduduk Tionghoa hidup secara berkelompok di kota-kota pesisir Jawa. Tahun 2005 orang Tionghoa di Indonesia berjumlah kurang lebih 6 juta orang berarti berkisar $3 \%$ dari seluruh jumlah orang Indonesia yang waktu itu berjumlah lebih dari 200 juta orang (Handinoto, 2009). Dari uraian tersebut dapat diketahui bahwa di Indonesia juga terdapat kelompok etnis Tionghoa. Oleh karena itu, penulis ingin mengetahui akurasi metode willems dalam estimasi usia anak etnis Tionghoa di Indonesia.

\section{Estimasi Usia}

\subsection{Usia}

\subsubsection{Usia Kronologis}

Usia kronologis merupakan usia yang dihitung berdasarkan tanggal kelahiran sampai dengan sekarang. Usia kronologis biasa didokumentasikan dalam bentuk akta kelahiran, rekam medis, kartu identitas, dan sebagainya (Adams et al, 2014). Penentuan usia berguna di bidang odontologi forensik dan kedokteran forensik untuk mengidentifikasi usia saat kematian seseorang yang belum diketahui identitasnya (Nik - Hussein et al, 2010). Prosedur penentuan usia merupakan proses yang rumit dan melibatkan banyak pertimbangan meliputi pertumbuhan tulang, karakter seksual sekunder dan maturasi gigi (Manisha et al, 2013). Salah satu metode yang paling akurat untuk estimasi usia kronologis pada anak-anak adalah melalui parameter gigi (Nik Hussein et al, 2010).

\subsubsection{Usia Dental}

Usia dental merupakan usia gigi yang ditentukan berdasarkan tahap erupsi gigi dan pembentukan gigi atau maturasi gigi. Tahap erupsi gigi diawali dengan penonjolan gingiva atau migrasi benih gigi ke arah oklusal. tahapan ini dapat dipengaruhi oleh beberapa faktor, antara lain ankilosis, pencabutan gigi sulung yang terlambat atau terlalu cepat, gigi permanen yang impaksi dan berdesakan. Pada tahap pembentukan gigi permanen tidak dipengaruhi oleh kehilangan gigi sulung (Demirjian et al, 1973). Pada tahun 1973 Demirjian membuat metode penilaian usia dental dengan menjumlahkan nilai 7 gigi kiri rahang bawah berdasarkan nilai 8 tahapan kalsifikasi gigi kemudian dikonversikan menjadi usia kronologis. Pada tahun 2001, Willems menyederhanakan metode Demirjian dengan membuat tabel penilaian kalsifikasi gigi yang dapat langsung mengekspresikan usia kronologis (Willems, 2001).

\subsection{Pertumbuhan dan Perkembangan Gigi}

Perkembangan gigi dapat dibagi menjadi dua fase, antara lain fase pembentukan gigi dan fase pertumbuhan gigi (erupsi gigi). Fase pembentukan gigi adalah fase mineralisasi gigi atau fase pembentukan enamel, dentin dan sementum yang terjadi di dalam tulang alveolar, sedangkan fase erupsi adalah fase pergerakan gigi pada arah aksial dari bagian dalam sampai ke puncak tulang alveolar dan selanjutnya mencapai level oklusi. Penonjolan gingiva merupakan bagian dari pertumbuhan gigi adalah cusp gigi secara klinis terlihat muncul menembus gingiva (Adams et al, 2014).

Kalsifikasi gigi desidui dimulai pada usia 4 bulan intra uterin. Selama proses perkembangan email dan dentin gigi dapat dijadikan sebagai perekam biologis kesehatan dan penyakit. Setelah proses pembentukan mahkota gigi dan pembentukan sebagian akar gigi, selanjutnya gigi akan menembus membran mukosa kemudian gigi erupsi kedalam rongga mulut. Selanjutnya akar gigi akan menjadi lebih aktif mengalami perkembangan dan mendorong mahkota gigi ke arah rongga mulut. Selanjutnya mahkota bergerak lebih jauh kearah oklusal dan memposisikan gigi dengan gigi antagonisnya didalam rongga mulut. Proses 
selanjutnya dilanjutkan dengan pembentukan akar gigi, dentin dan sementum (Nelson et al, 2010).

Pembentukan akar dimulai ketika gigi belum erupsi secara sempurna didalam rongga mulut, setelah akar terbentuk lengkap kemudian cementum gigi menutupi seluruh akar gigi. Selanjutnya terbentuk jaringan pulpa gigi yang berfungsi memberikan pasokan darah dan saraf pada gigi. Pulpa gigi merupakan organ yang berasal dari jaringan ikat yang mengandung pembuluh darah arteri, vena, sistem limpatik dan saraf, fungsi utamanya untuk membentuk dentin gigi (Nelson et al, 2010).

Pembentukan gigi dikatakan lengkap saat ujung apikal gigi selesai terbentuk. Proses ini akan terus berlangsung secara berlahan sepanjang kehidupan. Ketika gigi baru erupsi, pulpa gigi terlihat lebar, kemudian akan mengecil seiring proses pembentukan gigi selesai. Rongga pulpa akan menjadi lebih kecil dan menyempit karena adanya pembentukan dentin sekunder. Perubahan ruang pulpa ini dapat dihubungkan dengan pertambahan usia individu (Nelson et al, 2010).

\subsubsection{Tahap Perkembangan Gigi}

Tahap perkembangan adalah sebagai berikut (McDonald dan Avery, 2000; Finn, 2003) :

\section{Inisiasi (bud stage)}

Merupakan permulaan terbentuknya benih gigi dari epitel mulut. Sel-sel tertentu pada lapisan basal dari epitel mulut berproliferasi lebih cepat daripada sel sekitarnya. Hasilnya adalah lapisan epitel yang menebal di regio bukal lengkung gigi dan meluas sampai seluruh bagian rahang atas dan bawah.

\section{Proliferasi (cap stage)}

Lapisan sel-sel mesenkim yang berada pada lapisan dalam mengalami proliferasi, memadat, dan bervaskularisasi membentuk papil gigi yang kemudian membentuk dentin dan pulpa pada tahap ini. Selsel mesenkim yang berada di sekeliling organ gigi dan papila gigi memadat dan fibrous, disebut kantong gigi yang akan menjadi sementum, membran periodontal, dan tulang alveolar.

3. Histodiferensiasi (bell stage)

Terjadi diferensiasi seluler pada tahap ini. Sel-sel epitel email dalam (inner email epithelium) menjadi semakin panjang dan silindris, disebut sebagai ameloblas yang akan berdiferensiasi menjadi email dan selsel bagian tepi dari papila gigi menjadi odontoblas yang akan berdiferensiasi menjadi dentin.

4. Morfodiferensiasi

Sel pembentuk gigi tersusun sedemikian rupa dan dipersiapkan untuk menghasilkan bentuk dan ukuran gigi selanjutnya. Proses ini terjadi sebelum deposisi matriks dimulai. Morfologi gigi dapat ditentukan bila epitel email bagian dalam tersusun sedemikian rupa sehingga batas antara epitel email dan odontoblas merupakan gambaran dentinoenamel junction yang akan terbentuk. Dentinoenamel junction mempunyai sifat khusus yaitu bertindak sebagai pola pembentuk setiap macam gigi. Terdapat deposit email dan matriks dentin pada daerah tempat sel-sel ameloblas dan odontoblas yang akan menyempurnakan gigi sesuai dengan bentuk dan ukurannya.

\section{Aposisi}

Terjadi pembentukan matriks keras gigi baik pada email, dentin, dan sementum. Matriks email terbentuk dari sel-sel ameloblas yang bergerak ke arah tepi dan telah terjadi proses kalsifikasi sekitar 25\%-30\%.

\subsubsection{Tahap Kalsifikasi Gigi}

Tahap kalsifikasi adalah suatu tahap pengendapan matriks dan garam-garam kalsium. Kalsifikasi akan dimulai di dalam matriks yang sebelumnya telah mengalami deposisi dengan jalan presipitasi dari satu bagian ke bagian lainnya dengan penambahan lapis demi lapis. Gangguan pada tahap ini dapat menyebabkan kelainan pada kekerasan gigi seperti hipokalsifikasi. Tahap ini tidak sama pada setiap individu, dipengaruhi oleh faktor genetik atau keturunan. Faktor ini mempengaruhi pola kalsifikasi, bentuk mahkota dan komposisi mineralisasi. Kalsifikasi gigi permanen dimulai saat lahir, yaitu saat molar pertama permanen mulai terkalsifikasi (McDonald dan Avery, 2000).

\subsubsection{Tahap Erupsi Gigi}


Erupsi gigi merupakan suatu proses yang berkesinambungan dimulai dari awal pembentukan di dalam tulang alveolar sampai gigi muncul ke arah oklusal di rongga mulut Erupsi gigi merupakan proses yang kompleks dan terbagi dalam 5 tahap, yaitu gerakan preeruptif; tahap intraosseus; penetrasi mucosal; pre-oklusal; tahap post oklusal (Almonaitiene et al, 2010). Ada dua fase yang penting dalam proses erupsi gigi (Proffit dan Fields, 1993), yaitu erupsi aktif dan pasif. Erupsi aktif adalah pergerakan gigi yang didominasi oleh gerakan ke arah vertikal, sejak mahkota gigi bergerak dari tempat pembentukannya di dalam rahang sampai mencapai oklusi fungsional dalam rongga mulut,sedangkan erupsi pasif adalah pergerakan gusi ke arah apeks yang menyebabkan mahkota klinis bertambah panjang dan akar klinis bertambah pendek sebagai akibat adanya perubahan pada perlekatan epitel di daerah apikal.

\subsubsection{Waktu Erupsi Gigi Permanen}

Gigi permanen yang menggantikan gigi sulung disebut gigi pengganti (succestional teeth, succedaneus teeth), yaitu insisiv sentral permanen, insisiv lateral permanen, kaninus permanen masing-masing menggantikan insisiv sentral sulung, insisiv lateral sulung, kaninus sulung, sedangkan premolar pertama dan premolar kedua permanen menggantikan molar pertama sulung dan molar kedua sulung. Gigi permanen yang tumbuh di sebelah distal lengkung geligi sulung disebut gigi tambahan (accessional teeth, additional teeth), yaitu molar pertama permanen, molar kedua permanen dan molar ketiga.

Molar pertama permanen biasanya merupakan gigi permanen pertama yang erupsi pada umur sekitar lima sampai enam tahun. diduga aktivitas metabolism pada ligament periodontal mempengaruhi mekanisme erupsi gigi. diperlukan dua proses untuk erupsi gigi, yaitu resorpsi tulang alveolar dan akar gigi sulung sebagai jalan erupsi gigi serta mekanisme erupsi gigi itu sendiri menuju arah yang telah tersedia. Bila akar gigi telah terbentuk setengah sampai dua pertiga gigi tersebut siap untuk erupsi. Gingiva yang tebal atau adanya gigi kelebihan dapat mengganggu erupsi gigi, halangan mekanik ini dapat menyebabkan distorsi akar gigi yang disebut dilaserasi akar. Kadang-kadang insisiv sentral bawah merupakan gigi permanen pertama yang erupsi. Sebagaimana pada geligi sulung, saat dan urutan erupsi gigi permanen juga bervariasi sampai dengan 6 bulan lebih awal atau lebih lambat.

Bila sebuah gigi telah menembus gingiva, gigi tersebut bererupsi dengan cepat sampai hampir mencapai bidang oklusal. Kemudian gigi tersebut akan terkena pengaruh kekuatan kunyah dan kecepatan erupsi sangat berkurang dan berhenti sama sekali (Rahardjo P, 2009) .

Tabel 1: Masa erupsi gigi permanen (dalam tahun) (Rahardjo P, 2009)

\begin{tabular}{|c|c|c|c|c|}
\hline \multirow{2}{*}{$\begin{array}{l}\text { Gigi } \\
\text { Permanen }\end{array}$} & \multicolumn{2}{|c|}{ Kaukasoid } & \multicolumn{2}{|c|}{ Surabaya } \\
\hline & $\begin{array}{l}\text { Rahang } \\
\text { Atas }\end{array}$ & $\begin{array}{l}\text { Rahang } \\
\text { Bawah }\end{array}$ & $\begin{array}{l}\text { Rahang } \\
\text { Atas }\end{array}$ & $\begin{array}{l}\text { Rahang } \\
\text { Bawah }\end{array}$ \\
\hline $\begin{array}{l}\text { Insisiv } \\
\text { Sentral }\end{array}$ & 7 & 6 & $7-8$ & $6-7$ \\
\hline $\begin{array}{l}\text { Insisiv } \\
\text { Lateral }\end{array}$ & 8 & 7 & $8-9$ & $7-8$ \\
\hline Kaninus & 11 & 10 & $11-12$ & $9-11$ \\
\hline $\begin{array}{l}\text { Premolar } \\
\text { Pertama }\end{array}$ & 10 & 10 & $10-11$ & $10-12$ \\
\hline $\begin{array}{l}\text { Premolar } \\
\text { Kedua }\end{array}$ & 11 & 11 & $10-12$ & $11-12$ \\
\hline $\begin{array}{l}\text { Molar } \\
\text { Pertama }\end{array}$ & 6 & 6 & $6-7$ & 6 \\
\hline $\begin{array}{l}\text { Molar } \\
\text { Kedua }\end{array}$ & 12 & 12 & $12-13$ & 11-13 \\
\hline
\end{tabular}

\subsection{Faktor yang Mempengaruhi Pertumbuhan} dan Perkembangan Gigi

\subsubsection{Faktor Ras}

Perbedaan ras dapat menyebabkan perbedaan waktu dan urutan erupsi gigi permanen. Waktu erupsi gigi orang Eropa dan campuran Amerika dengan Eropa lebih lambat daripada waktu erupsi orang Amerika berkulit hitam dan Amerika Indian (ras mongoloid) (Moyers, 2001).

\subsubsection{Faktor Jenis Kelamin}

Beberapa penelitian menyatakan bahwa gigi permanen pada anak perempuan erupsi terlebih dahulu daripada anak laki-laki. Hal ini dikaitkan dengan saat awal maturasi gigi yang terjadi terlebih dahulu pada anak perempuan dibandingkan dengan anak laki-laki (Peedikayil, 2011).

Terdapat perbedaan growth spurt pada anak laki-laki dan perempuan, anak perempuan mengalami growth spurt lebih dulu daripada anak laki-laki. Growth spurt terjadi pada awal sesudah lahir dan pada usia sekitar 6 - 7 tahun yang terjadi selama kurang lebih 3 4 bulan. Growth spurt terjadi kembali pada 
anak perempuan sekitar usia 12 tahun dan 14 tahun pada anak laki-laki (Rahardjo P, 2009).

\subsubsection{Faktor Penyakit}

Gangguan pada erupsi gigi permanen dapat disebabkan oleh penyakit sistemik dan beberapa sindroma dari Cerebral Palsy, Dysosteosclerosis, Hypothyroidism, Hypopituitarism, Hypoparathyroidism, Pseudohypoparathyroidism (Almonaitiene et al, 2010).

\subsubsection{Faktor Lingkungan}

Pertumbuhan dan perkembangan gigi dipengaruhi oleh faktor lingkungan tetapi tidak banyak mengubah sesuatu yang telah ditentukan oleh faktor keturunan. Pengaruh faktor lingkungan terhadap waktu erupsi gigi adalah sekitar 20\% (Moyers, 2001). Faktorfaktor yang termasuk ke dalam faktor lingkungan antara lain:

1. Sosial Ekonomi

Beberapa penelitian menyatakan bahwa anak dengan tingkat sosioekonomi tinggi lebih cepat mengalami erupsi gigi dibandingkan dengan anak dengan tingkat sosioekonomi rendah. hal ini disebabkan karena anak dengan tingkat sosioekonomi tinggi mamapu mendapatkan pelayanan kesehatan dan nutrisi yang lebih baik yang berhubungan dengan pembentukan benih gigi lebih awal (Almonaitiene et al, 2010).

2. Nutrisi

Nutrisi sebagai faktor pertumbuhan dapat mempengaruhi erupsi dan proses kalsifikasi. Keterlambatan waktu erupsi gigi dapat dipengaruhi oleh faktor kekurangan nutrisi, seperti vitamin D dan gangguan kelenjar endokrin. Pengaruh faktor nutrisi terhadap perkembangan gigi adalah sekitar $1 \%$ (Moyers, 2001).

\subsection{Metode Estimasi Usia Anak dalam Odontologi Forensik}

\subsubsection{Metode Demirjian}

Pada tahun 1973, Demirjian membuat suatu metode perkiraan usia kronologis anak usia 3 tahun sampai 16 tahun. Demirjian membuat penilaian maturitas gigi dengan pendekatan proses pembentukan gigi untuk menilai usia dental sebagai indikator yang lebih akurat dibandingkan dengan proses erupsi gigi. Hal ini disebabkan karena erupsi gigi dipengaruhi oleh beberapa faktor lingkungan seperti ketersediaan tempat pada lengkung gigi, tanggalnya gigi sulung sebelum waktunya, gigi yang terletak miring dan gigi impaksi. Sebaliknya, perkiraan usia dental dengan menggunakan penilaian terhadap tahapan pembentukan gigi sedikit memperoleh pengaruh dari faktor lingkungan (Willems, 2001).

Demirjian membuat 8 tahapan kalsifikasi gigi dari tahap $\mathrm{A}$ sampai $\mathrm{H}$ dan tahap 0 mmenandakan belum ada kalsifikasi gigi yang terlihat pada foto panoramik. Penilaian ini diberikan pada gigi insisiv sentral, insisiv lateral, kaninus. premolar pertama, premolar kedua, molar pertama dan molar kedua sebelah kiri rahang bawah. Penilaian ini dibedakan pada masingmasing jenis benih gigi dari tahap pembentukan hingga kalsifikasi serta mencapai penutupan akar. Setiap gigi memiliki skor tersendiri dari tahapan kalsifikasi yang dialami. Sistem penilaian tahapan pembentukan gigi tersebut dibedakan antara anak laki-laki dan perempuan. Jumlah skor dari 7 gigi permanen tersebut merupakan nilai maturitas gigi atau usia dental yang kemudian dikonversikan menjadi perkiraan usia kronologis. Penilaian tingkat tumbuh kembang gigi ini dapat digunakan secara universal, namun perlu diperhatikan konversi terhadap usia dental tersebut serta pertimbangan terhadap populasinya (Demirjian et al, 1973).

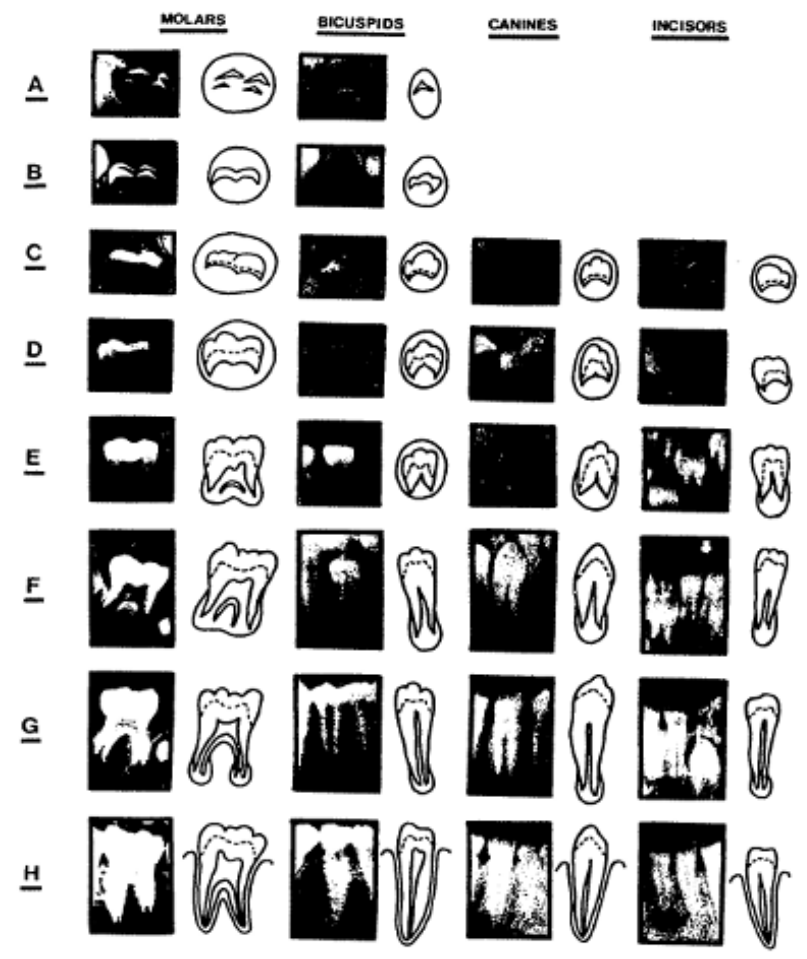


Gambar 1: Tahap pembentukan gigi permanen menurut Demirjian (Demirjian, 1973)

Tabel 2. Tahapan pembentukan gigi oleh Demirjian (Demirjian, 1973)

\begin{tabular}{|c|l|}
\hline Tahap & \multicolumn{1}{|c|}{ Keterangan } \\
\hline A & $\begin{array}{l}\text { Untuk gigi akar tunggal maupun } \\
\text { ganda, tahap kalsifikasi gigi dimulai } \\
\text { dari bagian tertinggi dari } \text { crypt }\end{array}$ \\
\hline B & $\begin{array}{l}\text { Ujung cusp yang mengalami } \\
\text { kalsifikasi menyatu, yang mulai } \\
\text { menunjukkan pola permukaan oklusal4. }\end{array}$ \\
\hline C & $\begin{array}{l}\text { a. Pembentukan enamel gigi selesai } \\
\text { pada permukaan oklusal. Tampak } \\
\text { perluasan dan pertemuan pada } \\
\text { bagian servikal gigi } \\
\text { b. Mulai terlihat deposit dentinal } \\
\text { c. Pola kamar pulpa tampak } \\
\text { berbentuk garis pada batas oklusal } \\
\text { gigi }\end{array}$ \\
\hline D & $\begin{array}{l}\text { a. Pembentukan mahkota gigi selesai, } \\
\text { dan terjadi perluasan menuju } \\
\text { cemento-enamel junction }\end{array}$ \\
& b. Tepi \\
\hline
\end{tabular}

\begin{tabular}{|c|l|}
\hline & \multicolumn{1}{|c|}{ panang dari tinggi mahkota } \\
\hline $\mathrm{G}$ & $\begin{array}{l}\text { Dinding saluran akar gigi tampak } \\
\text { sejajar namun ujung apikal gigi masih } \\
\text { terbuka }\end{array}$ \\
\hline $\mathrm{H}$ & $\begin{array}{l}\text { a. Ujung apikal gigi sudah tertutup } \\
\text { b. Membran periodontal memiliki } \\
\text { ketebalan yang sama di sekitar akar } \\
\text { gigi }\end{array}$ \\
\hline
\end{tabular}

b. Tepi atas kamar pulpa pada gigi yang berakar tunggal menunjukkan batas yang jelas, dan proyeksi tanduk pulpa memberikan gambaran seperti payung serta berbentuk trapezium pada gigi molar

c. Dimulainya pembentukan akar gigi

E $\quad$ Gigi berakar tunggal

a. Dinding kamar pulpa tampak sebagai garis lurus yang kontinuitasnya terputus akibat adanya tanduk pulpa

\section{Metode Willems}

Pada tahun 2001, Willems memperbaiki sistem penilaian usia dental metode Demirjian karena banyak literatur yang menyatakan bahwa perkiraan usia menggunakan metode Demirjian banyak yang memberikan hasil overestimasi pada usia kronologis pada populasi orang Belgia Kaukasian. Willems melakukan penelitian pada 2523 foto panoramik anak usia 2 tahun sampai 18 tahun yang terdiri dari 1265 anak laki-laki dan 1258 anak perempuan pada populasi Belgia Kaukasian dengan menggunakan tahapan kalsifikasi gigi permanen mulai tahapan A sampa $\mathrm{H}$ pada 7 gigi permanen kiri rahang bawah. Tabel penilaian tahapan kalsifikasi gigi dari masing-masing gigi permanen pada metode Demirjian dimodifikasi oleh Willems sehingga jumlah dari usia dental 7 gigi permanen tersebut dapat langsung mengekspresikan perkiraan usia kronologis pada anak laki-laki dan perempuan (Willems, 2001).

Tabel 3. Penilaian tahapan kalsifikasi pada 7

b. Panjang akar gigi kurang dari mahkota gigi

Gigi Molar

a. Inisiasi pembentukan bifurkasi al

b. Panjang akar gigi kurang dari mahkota gigi

F

Gigi berakar tunggal gigi kiri rahang bawah pada anak laki-laki menurut Willems (Willems, 2001)

\begin{tabular}{|c|c|c|c|c|c|c|c|c|}
\hline Tooth & A & B & $\mathrm{C}$ & D & E & $\mathrm{F}$ & G & $\mathrm{H}$ \\
\hline Central incisor & . & & 1.68 & 1.49 & 1.5 & 1.86 & 2.07 & 2.19 \\
\hline Lateral incisor & . & & 0.55 & 0.63 & 0.74 & 1.08 & 1.32 & 1.64 \\
\hline Canine & & & & 0.04 & 0.31 & 0.47 & 1.09 & 1.9 \\
\hline First bicuspid & 0.15 & 0.56 & 0.75 & 1.11 & 1.48 & 2.03 & 2.43 & 2.83 \\
\hline Second bicuspid & 0.08 & 0.05 & 0.12 & 0.27 & 0.33 & 0.45 & 0.4 & 1.15 \\
\hline First molar & & & & 0.69 & 1.14 & 1.6 & 1.95 & 2.15 \\
\hline Second molar & 0.18 & 0.48 & 0.71 & 0.8 & 1.31 & 2 & 2.48 & 4.17 \\
\hline
\end{tabular}

a. Dinding kamar pulpa tampak menyerupai segitiga sama kaki, dan ujung akar seperti corong

b. Panjang akar gigi sama atau lebih panjang dari tinggi mahkota gigi

Tabel 4. Penilaian tahapan kalsifikasi pada 7 gigi kiri rahang bawah pada anak perempuan menurut Willems (Willems, 2001)

Gigi Molar

a. Kalsifikasi pada bifurkasi mengalami perluasan, bentuk akar lebih nyata dan ujung akar tampak seperti corong

b. Panjang akar gigi sama atau lebih 
Hokkian merupakan orang Cina yang paling awal

\begin{tabular}{lccccccc}
\hline \multicolumn{1}{c}{ Tooth } & A & B & C & D & E & F & G \\
\hline Central incisor & $\ldots$ & $\ldots$ & 1.83 & 2.19 & 2.34 & 2.82 & 3.19 \\
Lateral incisor & $\ldots$ & $\ldots$ & $\ldots$ & 0.29 & 0.32 & 0.49 & 0.79 \\
Canine & $\ldots$ & $\ldots$ & 0.6 & 0.54 & 0.62 & 1.08 & 1.72 \\
First bicuspid & -0.95 & -0.15 & 0.16 & 0.41 & 0.6 & 1.27 & 1.58 \\
Second bicuspid & -0.19 & 0.01 & 0.27 & 0.17 & 0.35 & 0.35 & 0.55 \\
First molar & $\ldots$ & $\ldots$ & $\ldots$ & 0.62 & 0.9 & 1.56 & 1.82 \\
Second molar & 0.14 & 0.11 & 0.21 & 0.32 & 0.66 & 1.28 & 2.09 \\
\hline
\end{tabular}
dạn paling besar jumlahnya sebagai imigran. Mereka mempunyai budaya dan tradisi dagang d̆ang kuat sejak dari daerah asalnya. Orang Teociu zang berasal dari daerah pedalaman Swatow di bagian timur propinsi Kwantung mempunyai Kéahlian di bidang pertanian, sehingga mereka banyak tersebar di luar Jawa. Orang Hakka/Khek berasal dari daerah yang tidak subur di propinsi

\subsection{Etnis Tionghoa}

\subsubsection{Pengertian Etnis Tionghoa}

Istilah "Cina" dalam pers Indonesia tahun 1950-an telah diganti menjadi menjadi "Tionghoa" (sesuai ucapannya dalam bahasa Hokkian) untuk merujuk pada orang Cina dan "Tiongkok" untuk negara Cina dalam pers Indonesia 1950-an (Liem, 2000). Etnis Tionghoa menurut Purcell (Liem, 2000) adalah seluruh imigran negara Tiongkok dan keturunannya yang tinggal dalam ruang lingkup budaya Indonesia dan tidak tergantung dari kewarganegaraan mereka dan bahasa yang mereka gunakan. Etnis Tionghoa adalah individu yang memandang dirinya sebagai "Tionghoa" atau dianggap demikian oleh lingkungannya. Pada saat bersamaan mereka berhubungan dengan etnis Tionghoa perantauan lain atau negara Tiongkok secara sosial, tanpa memandang kebangsaan, bahasa, atau kaitan erat dengan budaya Tiongkok.

Menurut Liem (2000) etnis Tionghoa di Indonesia yaitu orang Indonesia yang berasal dari negara Tiongkok dan sejak generasi pertama/kedua telah tinggal di negara Indonesia, dan berbaur dengan penduduk setempat, serta menguasai satu atau lebih bahasa yang dipakai di Indonesia. Sedangkan menurut Suryadinata (1981) istilah Tionghoa Indonesia digunakan merujuk pada etnis Tionghoa yang tinggal di negara Indonesia yang memiliki nama keluarga (marga), tanpa memandang kewarganegaraannya.

\subsubsection{Etnis Tionghoa di Indonesia}

Orang Tionghoa di Indonesia sebenarnya bukan merupakan satu kelompok yang berasal dari satu daerah di negara Cina, tetapi terdiri dari beberapa suku bangsa yang berasal dari dua propinsi yaitu Fukien dan Kwantung yang sangat berpencar daerahnya (Koentjaraningrat, 1971).

Orang-orang Cina yang datang ke Indonesia pada umumnya dan di wilayah pesisir utara Jawa khususnya, sebagian besar berasal dari propinsi Fukien/Fujian dan Kwang Tung. Mereka ini terdiri dari berbagai suku bangsa yaitu Hokkian, Hakka, Teociu dan Kanton. Mereka mempunyai bidang keahlian yang berbeda-beda, yang nantinya dikembangkan di tempat baru (Indonesia). Orang
Kwang Tung, sehingga mereka berimigrasi karena kesulitan hidup. Di antara orang-orang Cina yang datang ke Indonesia mereka merupakan golongan yang paling miskin. Orang-orang Hakka dan orangorang Teociu sebagian besar bekerja di daerahdaerah pertambangan di Indonesia seperti Kalimantan Barat, Bangka, Belitung dan Sumatra. Perkembangan kota-kota besar di Jawa seperti kota Jakarta dan dibukanya daerah Priangan bagi pedagang Cina telah menarik minat orang-orang Hakka dan Teociu untuk pindah ke Jawa Barat (Koentjaraningrat, 2002). Pada perkembangannya kemudian mereka menyebar dan menetap di kotakota lain di Jawa. Orang Kanton yang mempunyai keahlian di bidang pertukangan dan industri datang ke Indonesia dengan modal finansial dan ketrampilan yang cukup, sehingga di tempat yang baru mereka dapat mengembangkan usaha di bidang pertukangan, industri, rumah makan, perhotelan dan lain sebagainya (Tan, Melly G , 1981).

\subsubsection{Etnis Tionghoa di Surabaya}

Komposisi etnis di Indonesia sangat bervariasi karena memiliki ratusan ragam suku dan budaya. Menurut sensus BPS tahun 2010 terdapat lebih dari 300 kelompok etnik atau suku bangsa di Indonesia atau tepatnya 1.340 suku bangsa. Jawa Barat, Jawa Timur dan Jawa Tengah adalah tiga provinsi dengan urutan teratas yang berpenduduk terbanyak, yaitu masing-masing berjumlah 43.021.826 jiwa, 37.476.757 jiwa, dan 32.380.687 jiwa. Dari 37.476.757 jiwa penduduk Jawa Timur, persentase terbesar adalah etnik Jawa $(79.58 \%)$ yang disusul kemudian etnik Madura (17.53\%). Menurut sensus penduduk tahun 2010, kota Surabaya memiliki penduduk sebanyak 2.765.908 jiwa. Kepadatan penduduk kota Surabaya adalah sebesar 8.304 jiwa per $\mathrm{km}^{2}$ dengan wilayah seluas $333.063 \mathrm{~km}^{2}$ (Badan Pusat Statistik, 2010). Suku Jawa adalah suku bangsa mayoritas di Surabaya. Meskipun Jawa adalah suku mayoritas $(83,68 \%)$, tetapi Surabaya juga menjadi tempat tinggal berbagai suku bangsa di Indonesia, termasuk suku Madura (7,5\%), Tionghoa (7,25\%), Arab (2,04\%), dan sisanya merupakan suku bangsa lain seperti Bali, Batak, 
Bugis, Banjar, Manado, Minangkabau, Dayak, Toraja, Ambon, dan Aceh atau warga asing (Wikipedia, 2015).

Sejarah berkata bahwa bangsa Tionghoa adalah bangsa yang ekspansif. Mereka menyebar ke berbagai belahan dunia. Jiwa ekspansif ini dipicu oleh karakter budaya mereka yaitu berdagang. Salah satu tujuan persebaran mereka adalah Indonesia lebih tepatnya di Surabaya. Selain jalur darat, jalur laut mereka pilih karena dirasa lebih efektif dan menjangkau hingga ke pelosok nusantara. Kala itu etnis Tionghoa tertuju pada kota Surabaya yang memang terletak di pesisiran pantai utara Jawa. Tak heran bila kini mereka telah menjadi bagian hidup kita, orang pribumi. Dari catatan sejarah, etnis Tionghoa singgah ke Indonesia untuk pertama kalinya melalui ekspedisi Laksamana Haji Muhammad Cheng Hoo (14051433). Laksamana Cheng Hoo sengaja berkeliling dunia dengan misi utama membuka jalur perdagangan sutera dan keramik. Dengan adanya hal tersebut, nampaknya jiwa bisnis sudah kentara pada diri etnis Tionghoa. Prinsip hidup mereka adalah kemakmuran. Buktinya adalah, semenjak ekspedisi Cheng Hoo tersebut, warga etnis Tionghoa berangsur-angsur berdatangan ke Indonesia untuk melakukan perdagangan besarbesaran, sebut saja etnis Tionghoa dengan "pecinan". "Surabaya menjadi sasaran gerakan kebangkitan etnis Tionghoa, sebab ada kali Brantas, dan Kalimas sebagai pusat transoprtasi jalur air." Singgahnya etnis Cina di pesisiran Jawa menghadirkan generasi baru dari mereka yang menetap dan kawin dengan rakyat pribumi (Noordjanah A, 2004).

\section{METODE PENELITIAN}

Jenis penelitian ini adalah jenis penelitian analitik observasional. Penelitian ini mengggunakan populasi sampel radiograf panoramik anak usia 6-13 tahun etnis Tionghoa denan besar sampel 76 yang terdri dari 32 anak laki-laki dan 44 anak perempuan.

Sampel penelitian diambil secara simple random sampling pada radiogram panoramik yang memenuhi kriteria sebagai berikut:

a. Radiogram panoramik yang akan diteliti merupakan milik anak usia 6-13 tahun.

b. Radiogram panoramik milik subyek yang merupakan keturunan etnis Tionghoa hingga 3 generasi di atasnya..

c. Ketujuh gigi permanen bawah kanan dan kiri lengkap baik sudah erupsi maupun belum erupsi. d. Radiogram panoramik berasal dari anak yang tidak memiliki kelainan pertumbuhan, endokrin, gangguan nutrisi, tidak pernah mengalami trauma atau cacat pada daerah kraniofasial yang dapat mempengaruhi pertumbuhan dan perkembangan gigi.

e. Radiogram panoramik harus dapat jelas terbaca

Prosedur penelitian meliputi:

a) Sampel radiogram panoramik didapat dari pasien anak antara usia 6 - 13 tahun yang datang ke Dr. Daniels's Aesthetic Dental Cinic yang memenuhi kriteria dan bersedia menandatangani inform consent.

b) Pasien mengisi kuisioner yang telah disediakan peneliti.

c) Dilakukan pencatatan usia kronologis seperti yang tertera pada sampul radiogram dan kartu status pasien.

d) Radiogram panoramik diletakkan pada viewer.

e) Menghitung usia dental dengan metode Willems, dengan cara menilai tahap perkembangan atau kalsifikasi tujuh gigi rahang bawah kiri yang dilihat melalui gambaran radiogram panoramik. Masingmasing gigi tersebut diberikan skor berdasarkan tahapan kalsifikasi yang dialami. Skor dari tujuh gigi tersebut dijumlahkan dan hasilnya merupakan usia dental.

f) Menghitung perbedaan antara usia dental dan usia kronologis. Jika usia dental kurang atau lebih dari sama dengan 0,5 tahun maka dianggap sama. Selain itu, dianggap berbeda.

g) Membandingkan usia kronologis dengan usia dental melalui uji statistik paired $t$ test untuk mengetahui ada atau tidak perbedaan diantara keduanya.

h) Membandingkan usia kronologis dan usia dental pada sampel laki - laki dan perempuan.

Dari data yang diperoleh, yaitu usia kronologis pasien yang sebenarnya dan perkiraan usia pasien berdasarkan metode Willems, akan diuji apakah terdapat perbedaan yang signifikan. Uji statistik yang digunakan adalah paired t test.

\section{HASIL DAN PEMBAHASAN}

Penelitian dilakukan terhadap 76 sampel yang telah memenuhi kriteria. Berdasarkan 
penelitian yang telah dilakukan, didapatkan hasil sebagai berikut:

Tabel 5: Rata-rata dan Standar Deviasi Nilai Usia Kronologis dan Usia Dental

\begin{tabular}{|l|c|l|l|}
\hline Pengamatan & N & \multicolumn{3}{|l|}{ Rata-rata \pm SD } \\
\cline { 3 - 4 } & & $\begin{array}{l}\text { Usia } \\
\text { Kronologis }\end{array}$ & $\begin{array}{l}\text { Usia } \\
\text { Dental }\end{array}$ \\
\hline Laki-laki & 32 & $10.86 \pm 1.45$ & $10.84 \pm 1.47$ \\
\hline Perempuan & 44 & $11.39 \pm 1.46$ & $11.14 \pm 1.61$ \\
\hline $\begin{array}{l}\text { Laki-laki + } \\
\text { Perempuan }\end{array}$ & 76 & $11.17 \pm 1.47$ & $11.01 \pm 1.55$ \\
\hline
\end{tabular}

Keterangan : SD = Standar Deviasi $\mathrm{N}=$ Jumlah sampel

Tabel 5 menunjukkan hasil penelitian dari 76 sampel yang terdiri dari 44 sampel anak perempuan dan 32 sampel anak laki-laki. Berdasarkan hasil penelitian tersebut, didapatkan usia kronologis dari keseluruhan sampel rata-rata 11.17 dan standar deviasi 1.47, sedangkan usia dental dari keseluruhan sampel rata-rata 11.01 dan standar deviasi 1.55. Pada sampel anak perempuan didapatkan hasil usia kronologis rata-rata 11.39 dan standar deviasi 1.46, sedangkan usia dental ratarata 11.14 dan standar deviasi 1.61. Pada sampel anak laki-laki didapatkan hasil usia kronologis rata-rata 10.86 dan standar deviasi 1.45 , sedangkan usia dental rata-rata 10.84 dan stadar deviasi 1.47.

Data tersebut diuji normalitas dengan menggunakan One Kolmogorov Smirnov test untuk mengetahui data berdistribusi normal atau tidak. Jika hasil uji tersebut menyatakan data berdistribusi normal, maka dilanjutkan dengan uji beda Paired Samples T-test. Jika hasil uji normalitas menyatakan data tidak berdistribusi normal, maka dilanjutkan dengan uji beda Wilcoxon. Hasilnya adalah sebagai berikut:

Tabel 6: Uji Normalitas One Kolmogorov Smirnov Test

\begin{tabular}{|l|l|l|l|l|}
\hline No. & $\begin{array}{l}\text { Jenis } \\
\text { kelamin }\end{array}$ & Pengamatan & $\begin{array}{l}\text { Signifi } \\
\text { kasi } \\
(\mathbf{p})\end{array}$ & Keterangan \\
\hline 1 & $\begin{array}{l}\text { Laki - laki }+ \\
\text { Perempuan }\end{array}$ & $\begin{array}{l}\text { Usia } \\
\text { Kronologis }\end{array}$ & 0.096 & $\begin{array}{l}\text { Distribusi } \\
\text { normal }\end{array}$ \\
\cline { 3 - 5 } & Usia Dental & 0.200 & $\begin{array}{l}\text { Distribusi } \\
\text { normal }\end{array}$ \\
\hline 2 & Perempuan & $\begin{array}{l}\text { Usia } \\
\text { Kronologis }\end{array}$ & 0.034 & $\begin{array}{l}\text { Distribusi tidak } \\
\text { normal }\end{array}$ \\
\cline { 3 - 5 } & Usia Dental & 0.022 & $\begin{array}{l}\text { Distribusi tidak } \\
\text { normal }\end{array}$ \\
\hline 3. & \multirow{2}{*}{ Laki-laki } & $\begin{array}{l}\text { Usia } \\
\text { Kronologis }\end{array}$ & 0.200 & $\begin{array}{l}\text { Distribusi } \\
\text { normal }\end{array}$ \\
\cline { 3 - 5 } & & Usia Dental & 0.200 & $\begin{array}{l}\text { Distribusi } \\
\text { normal }\end{array}$ \\
\hline
\end{tabular}

Keterangan: Uji Kolmogorov-Smirnov : $p>0,05$ (distribusi normal), $p<0,05$ (distribusi tidak normal)
Berdasarkan hasil uji normalitas dengan menggunakan uji One Kolmogorov Smirnov test diketahui variabel usia kronologis gabungan anak laki-laki dan perempuan memiliki nilai signifikan $\mathrm{p}=0,096$, sedangkan usia dental gabungan anak laki-laki dan perempuan memiliki nilai signifikan $\mathrm{p}=0,200$. Variabel usia kronologis anak perempuan memiliki nilai signifikan $\mathrm{p}=0,034$ sedangkan nilai signifikansi usia dental anak-anak perempuan pada penelitian ini adalah $\mathrm{p}=0,022$. Variabel usia kronologis pada anak laki-laki memiliki nilai signifikansi $\mathrm{p}=0,200$, sedangkan pada variabel usia dental nilai signifikansi sebesar $\mathrm{p}=0,200$. Variabel usia kronologis laki-laki + perempuan, usia dental laki-laki + perempuan, usia kronologis laki-laki dan usia dental laki-laki memiliki nilai signifikansi p>0.05 yang menunjukkan bahwa data berdistribusi normal sehingga dapat dilanjutkan dengan uji komparasi Paired T Test. Variabel usia kronologis perempuan dan usia dental perempuan mempunyai nilai signifikan $\mathrm{p}<0.05$ yang menunjukkan bahwa data tidak berdistribusi normal sehingga dilanjutkan uji komparasi dengan menggunakan uji Wilcoxon.

\section{Tabel 7. Uji Komparasi}

\begin{tabular}{|c|l|l|l|l|l|}
\hline $\begin{array}{l}\text { N } \\
\text { o } \\
\cdot\end{array}$ & $\begin{array}{l}\text { Jenis } \\
\text { kelamin }\end{array}$ & Pengamatan & $\begin{array}{l}\text { Uji } \\
\text { Kompara } \\
\text { si }\end{array}$ & $\begin{array}{l}\text { Nilai } \\
\text { signifikansi } \\
\text { (p) }\end{array}$ & Ket \\
\hline 1 & $\begin{array}{l}\text { Laki }- \\
\text { laki }\end{array}$ & $\begin{array}{l}\text { Usia } \\
\text { kronologis } \\
\text { dengan usia } \\
\text { dental }\end{array}$ & $\begin{array}{l}\text { Paired T } \\
\text { Test }\end{array}$ & 0,126 & $\begin{array}{l}\text { Tidak } \\
\text { ada } \\
\text { perbeda } \\
\text { an }\end{array}$ \\
\hline 2 & $\begin{array}{l}\text { Perempu } \\
\text { an }\end{array}$ & $\begin{array}{l}\text { Usia } \\
\text { kronologis } \\
\text { dengan usia } \\
\text { dental }\end{array}$ & Wilcoxon & 0,053 & $\begin{array}{l}\text { Tidak } \\
\text { ada } \\
\text { perbeda } \\
\text { an }\end{array}$ \\
\hline 3 & $\begin{array}{l}\text { Laki }- \\
\text { laki }+ \\
\text { Perempu } \\
\text { an }\end{array}$ & $\begin{array}{l}\text { Usia } \\
\text { kronologis } \\
\text { dengan usia } \\
\text { dental }\end{array}$ & $\begin{array}{l}\text { Paired Test } \\
\text { Tent }\end{array}$ & 0,843 & $\begin{array}{l}\text { Tidak } \\
\text { ada } \\
\text { perbeda } \\
\text { an }\end{array}$ \\
\hline
\end{tabular}

Keterangan : $p<0,05$ : signifikan / ada perbedaan yang bermakna; p>0,05: tidak signifikan / tidak ada perbedaan yang bermakna

Berdasarkan hasil uji komparasi dengan menggunakan uji Paired $T$ Test menunjukkan bahwa tidak ada perbedaan yang signifikan antara usia kronologis laki-laki dengan usia dental lakilaki dengan nilai $\mathrm{p}=0,126$ ( $\mathrm{p}>0,05)$, dan tidak ada perbedaan yang signifikan antara usia kronologis laki-laki+perempuan dengan usia dental lakilaki+perempuan dengan nilai $p=0,843 \quad(p>0,05)$. Pada variabel usia kronologis perempuan dan usia dental perempuan juga telah dilakukan uji komparasi dengan menggunakan uji Wilcoxon dengan hasil nilai signifikansi $\mathrm{p}=0,053$ ( $\mathrm{p}>0.05)$ yang berarti bahwa tidak ada perbedaan yang 
signifikan antara usia kronologis perempuan dengan usia dental perempuan. Hal tersebut menunjukkan bahwa metode Willems dapat digunakan untuk menghitung estimasi usia pada anak etnis Tionghoa.

Tabel 8 Rata-rata usia kronologis, rata-rata usia dental dan rata-rata selisih usia kelompok perempuan

\begin{tabular}{|c|c|c|c|}
\hline $\begin{array}{c}\text { Kelompok Usia } \\
\text { (thn) }\end{array}$ & $\begin{array}{c}\text { Rata-rata Usia } \\
\text { Kronologis (thn) }\end{array}$ & $\begin{array}{c}\text { Rata-rata } \\
\text { Usia Dental } \\
\text { (thn) }\end{array}$ & $\begin{array}{c}\text { Rata-rata } \\
\text { Selisih Usia } \\
\text { (thn) }\end{array}$ \\
\hline 6 & & & \\
\hline 7 & 8.73 & 8.31 & -0.42 \\
\hline 8 & 9.69 & 10.64 & 0.95 \\
\hline 9 & 10.51 & 10.53 & 0.02 \\
\hline 10 & 11.27 & 10.55 & -0.72 \\
\hline 11 & 12.53 & 11.93 & -0.6 \\
\hline 12 & 13.35 & 13.18 & -0.17 \\
\hline 13 & 11.39 & 11.14 & -0.25 \\
\hline Total: & & & \\
\hline
\end{tabular}

Tabel 8 menunjukkan rata-rata selisih usia dental dengan usia kronologis anak perempuan sebesar $-0,25$. Hal ini berarti bahwa estimasi usia dental pada anak perempuan lebih muda 0,258 tahun dibandingkan dengan usia kronologis. berdasarkan tabel 8, rata-rata selisih usia terbesar pada anak perempuan terjadi pada kelompok usia 9 tahun yaitu sebesar 0,95 tahun.

Tabel 9 Rata-rata usia kronologis, rata-rata usia dental dan selisih usia kelompok laki-laki

\begin{tabular}{|c|c|c|c|}
\hline $\begin{array}{c}\text { Kelompok Usia } \\
\text { (thn) }\end{array}$ & $\begin{array}{c}\text { Rata-rata Usia } \\
\text { Kronologis }\end{array}$ & $\begin{array}{c}\text { Rata-rata } \\
\text { Usia }\end{array}$ & $\begin{array}{c}\text { Rata-rata } \\
\text { Selisih }\end{array}$ \\
\hline 6 & 6.83 & 6.32 & -0.51 \\
\hline 7 & & & \\
\hline 8 & 8.7 & 9.01 & 0.31 \\
\hline 9 & 9.63 & 9.83 & 0.19 \\
\hline 10 & 10.34 & 10.41 & 0.07 \\
\hline 11 & 11.45 & 11.64 & 0.19 \\
\hline 12 & 12.28 & 11.79 & -0.49 \\
\hline 13 & 13.14 & 12.58 & -0.56 \\
\hline Total: & 10.86 & 10.83 & -0.03 \\
\hline
\end{tabular}

Tabel 9 menunjukkan rata-rata selisih usia dental dengan usia kronologis anak laki-laki sebesar -0,03. Hal ini berarti bahwa estimasi usia dental pada anak laki-laki lebih muda 0,03 tahun dibandingkan dengan usia kronologis. Berdasarkan tabel 5.5, rata-rata selisih usia terbesar pada anak laki-laki terjadi pada kelompok usia 13 tahun yaitu sebesar $-0,56$ tahun.
Menurut Liem (2000) etnis Tionghoa di Indonesia yaitu orang Indonesia yang berasal dari negara Tiongkok dan sejak generasi pertama/kedua telah tinggal di negara Indonesia, dan berbaur dengan penduduk setempat, serta menguasai satu atau lebih bahasa yang dipakai di Indonesia. Orang Tionghoa di Indonesia sebenarnya bukan merupakan satu kelompok yang berasal dari satu daerah di negara Cina, tetapi terdiri dari beberapa suku bangsa yang berasal dari dua propinsi yaitu Fukien dan Kwantung yang sangat berpencar daerahnya (Koentjaraningrat, 1971). Menurut sensus penduduk tahun 2010, kota Surabaya memiliki penduduk sebanyak 2.765.908 jiwa. Kepadatan penduduk kota Surabaya adalah sebesar 8.304 jiwa per $\mathrm{km}^{2}$ dengan wilayah seluas 333.063 $\mathrm{km}^{2}$ (Badan Pusat Statistik, 2010). Suku Jawa adalah suku bangsa mayoritas di Surabaya. Meskipun Jawa adalah suku mayoritas $(83,68 \%)$, tetapi Surabaya juga menjadi tempat tinggal berbagai suku bangsa di Indonesia, termasuk Tionghoa sebesar 7,25\% dari jumlah penduduk di Surabaya (Wikipedia, 2015).

Berbagai kejadian yang memakan banyak korban jiwa, terutama sejak kejadian Bom Bali I membuat kegiatan identifikasi korban bencana massal (Disaster Victim Identification) menjadi kegiatan yang penting dan dilaksanakan hampir pada setiap kejadian yang menimbulkan korban jiwa dalam jumlah yang banyak. Seperti pada kasus pesawat Air Asia QZ8501 penerbangan dari Surabaya menuju Singapura yang jatuh di selat Karimata pada 28 Desember 2014 dengan jumlah korban 162 penumpang dan kru didominasi oleh etnis Tionghoa yang berasal dari Indonesia (Wikipedia, 2016). Tujuan utama pemeriksaan identifikasi pada kasus musibah bencana massal adalah untuk mengenali korban (Prawestiningtyas E, dkk, 2009).

Dalam kasus bencana massal, estimasi usia dapat menjadikan identifikasi korban lebih sederhana dengan mengelompokkan usia korban. Bagian tubuh yang umumnya dipakai untuk estimasi usia adalah skeletal dan gigi. Kematangan skeletal sebagai media estimasi usia memiliki keterbatasan karena hanya dapat mengestimasi usia pada rentang usia tertentu dengan simpangan baku usia yang besar sedangkan gigi sebagai media estimasi usia memiliki beberapa keunggulan, salah satunya adalah dapat mengestimasi usia pada individu dari usia prenatal sampai usia dewasa (Putri A.S, dkk, 2013). 
Usia dental berhubungan erat dengan usia kronologis dalam perkembangan anak. Kalsifikasi gigi lebih banyak digunakan untuk menilai maturitas gigi daripada erupsi gigi. Hal ini disebabkan karena kalsifikasi gigi merupakan proses yang berkesinambungan dan progresif serta panduan radiografis dapat dilakukan untuk evaluasi gigi pada setiap pemeriksaan (Kurita et al, 2007). Metode yang dipilih oleh peneliti adalah metode Willems karena menurut beberapa penelitian seperti penelitian Willems (2001) pada populasi anak Belgia, Ye X et al (2014) pada anak-anak populasi Cina, Nikk-Husein N N et al (2011) pada populasi anak Malaysia, Ambarkova V et al (2013) pada populasi anak Yugoslav Republik Macedonia, metode Willems ternyata lebih akurat jika dibanding dengan metode Demirjian yang juga menggunakan kalsifikasi gigi untuk estimasi usia anak. Metode Willems merupakan modifikasi dari metode Demirjian. Pada tahun 2001, Willems merevisi sistem penilaian metode Demirjian karena berdasarkan dari beberapa penelitian yang ditemukan dari metode Demirjian hasilnya mengalami perbedaan usia dental yang tinggi dari usia kronologis anak (Willems et al, 2001).

Willems memperkirakan usia kronologis dengan menghitung usia dental yang dilihat dari tahapan kalsifikasi mahkota dan akar yang berkaitan dengan penutupan apeks pada tujuh gigi permanen rahang bawah kiri., yaitu gigi 31, 32, 33, 34, 35, 36, 37. Tahap kalsifikasi dibagi dari $\mathrm{A}-\mathrm{H}$ dan masing-masing tahapan dari ketujuh gigi tersebut memiliki skor sendiri. Jumlah skor ketujuh gigi tersebut merupakan estimasi usia dental (Willems et al, 2001).

Peneliti memilih populasi sampel anakanak Tionghoa yang berumur $6-13$ tahun terdiri dari 44 sampel anak perempuan dan 32 sampel anak laki-laki Pada usia 6-13 tahun anak-anak mengalami masa gigi pergantian sehingga sesuai dengan kriteria yang ditentukan Willems. Willems juga menentukan kriteria sampel lainnya antara lain: sampel tidak mempunyai riwayat penyakit sistemik,kelahiran premature, kelainan kongenital, tidak ada anomali pada pertumbuhan gigi geligi rahang bawah sebab dapat mempengaruhi maturasi gigi (Willems,2001).

Data yang diperoleh diuji normalitas dengan menggunakan uji One Kolmogorov Smirnov sehingga didapatkan hasil bahwa kelompok variabel usia kronologis laki-laki + perempuan, usia dental laki-laki + perempuan, usia kronologis laki-laki dan usi dental laki-laki memiliki nilai signifikansi $\mathrm{p}>0.05$ yang menunjukkan bahwa data berdistribusi normal sehingga dapat dilanjutkan dengan uji komparasi Paired T Test. Variabel usia kronologis perempuan dan usia dental perempuan mempunyai nilai signifikan $\mathrm{p}<0.05$ yang menunjukkan bahwa data tidak berdistribusi normal sehingga dilanjutkan uji komparasi dengan menggunakan uji Wilcoxon. Dari hasil uji komparasi yang telah dilakukan, didapatkan hasil bahwa tidak ada perbedaan yang signifikan antara usia kronologis laki-laki dengan usia dental laki-laki, tidak ada perbedaan yang signifikan antara usia kronologis perempuan dengan usia dental perempuan, dan tidak ada perbedaan yang signifikan antara usia kronologis gabungan laki-laki+perempuan dengan usia dental gabungan laki-laki+perempuan. Hal ini sesuai dengan penelitian sebelumnya yang dilakukan Ye $X$ et al (2014) bahwa tidak ada perbedaan yang signikan antara usia kronologis dan usia dental.

Penelitian ini menunjukkan rata-rata selisih usia dental dengan usia kronologis anak perempuan sebesar $-0,25$ yang berarti bahwa estimasi usia dental pada anak perempuan lebih muda 0,25 tahun dibandingkan dengan usia kronologis. Sedangkan pada anak laki-laki, ratarata selisih usia dental dengan usia kronologis sebesar $-0,03$ yang berarti bahwa estimasi usia dental pada anak laki-laki lebih muda 0,03 tahun dibandingkan dengan usia kronologis. Beberapa peneliti telah melakukan penelitian yang serupa seperti penelitian yang dilakukan $\mathrm{Ye} X$ et al (2014) pada populasi anak Cina dengan hasil ratarata selisih usia kronologis dengan dental pada anak laki-laki sebesar 0,36 dan pada anak perempuan -0,02, pada penelitian Nik-Husein et al (2011) pada populasi anak Malaysia dengan ratarata selisih usia dental dengan usia kronologis pada anak perempuan sebesar 0,1 dan pada anak lakilaki sebesar 0,2, pada penelitian Ambarkova $\mathrm{V}$ et al (2014) dengan rata-rata selisih usia dental dengan kronologis anak laki-laki sebesar 0,52 dan pada anak perempuan 0,33 . Perbedaan hasil penelitian ini kemungkinan dapat disebabkan oleh perbedaan kultur dan budaya pada masing-masing populasi. Selain itu juga dapat disebabkan oleh perbedaan faktor lingkungan, kebiasaan makan yang bervariasi antar populasi, malnutrisi dan sosialekonomi yang berdampak pada maturasi gigi dan skeletal (Nik-Husein et al, 2011).

$$
\text { Penelitian Willems }
$$

mengemukakan adanya perbedaan hasil penelitian pada populasi yang berbeda dikarenakan adanya cara pengukuran secara subjektif, hal ini bisa menimbulkan perbedaan hasil observasi apabila pengukuran dilakukan oleh dua orang yang berbeda. Hal lain yang mempengaruhi hasil 
observasi metode ini yaitu adanya pengaruh asupan gizi. Seperti yang diketahui asupan gizi merupakan faktor penting dalam proses pertumbuhan dan perkembangan gigi geligi. Faktor gizi erat kaitannya dengan tingkat sosial ekonomi seseorang. Individu dengan tingkat sosial ekonomi yang baik menunjukkan waktu erupsi yang lebih cepat dibandingkan dengan individu dengan tingkat sosial ekonomi yang rendah.

Maber et al (2006) dan Liversidge (2012) menyatakan bahwa adanya perbedaan hasil penelitian dapat disebabkan karena adanya perbedaan diantara populasi sampel dan standar populasi yang berhubungan dengan perbedaan variabel meliputi usia, besar sampel, bias sampel, variasi biologis dari populasi sampel, lingkungan, kebiasaan makan dan ketepatan dalam mengevalusi metode yang digunakan.

Walaupun ada perbedaan hasil penelitian, selisih usia kronologis dengan usia dental masingmasing penelitian masih dalam batasan yang ditentukan oleh anthropologi forensik yaitu antara $\pm 0,5$ tahun sampai \pm 1 tahun baik pada populasi anak-anak maupun dewasa (Ambarkova V, 2014).

Perbandingan selisih usia kronologis dengan usia dental pada kelompok usia sampel menunjukkan adanya perbedaan selisih usia antara sampel laki-laki dan perempuan di masing-masing kelompok. Pada sampel anak perempuan rata-rata selisih usia kronologis dengan dental terbesar terjadi pada kelompok usia 9 tahun yaitu sebesar 0,95 tahun, sedangkan rata-rata selisih usia kronologis dengan usia dental terbesar pada sampel anak laki-laki sebesar $-0,56$ tahun pada kelompok usia 13 tahun. Adanya perbedaan selisih usia antara sampel laki-laki dan perempuan ini menunjukkan bahwa pada anak perempuan mengalami maturasi gigi terlebih dahulu daripada anak laki-laki. Hal ini disesuaikan juga dengan parameter maturasi lainnya pada tahap perkembangan anak perempuan seperti tinggi, maturasi seksual, dan perkembangan skeletal (Nik-Husein, 2011).

Percepatan maturasi gigi yang terjadi sering dikaitkan dengan proses growth spurt yang menyebabkan adanya lonjakan usia gigi yang tinggi dalam satu periode usia. Terdapat perbedaan growth spurt pada anak laki-laki dan perempuan, anak perempuan mengalami growth spurt lebih dulu daripada anak laki-laki. Growth spurt terjadi pada awal sesudah lahir dan pada usia sekitar $6-7$ tahun yang terjadi selama kurang lebih $3-4$ bulan. Percepatan pertumbuhan terjadi kembali pada anak perempuan usia kurang lebih 12 tahun dan 14 tahun pada anak laki-laki. Beberapa pustaka menyebutkan bahwa percepatan pertumbuhan terjadi $6-12$ bulan sebelum menstruasi pertama pada anak perempuan. Terdapat variasi percepatan pertumbuhan yang besar dengan standar deviasi 1 tahun bahkan kadang-kadang dapat terjadi pada usia 16 tahun pada laki-laki. (Rahardjo P, 2009).

Pada penelitian Ye X et al (2014) didapatkan hasil selisih usia dental dengan usia kronologis sampel anak laki-laki pada kelompok usia 14 tahun yaitu sebesar 0,84, sedangkan sampel anak perempuan pada kelompok usia 8 tahun sebesar -0.55. Pada penelitian Ambarkova V et al (2014) didapatkan hasil selisih usia dental dengan usia kronologis sampel anak laki-laki pada kelompok usia 6 tahun yaitu sebesar 0,76, sedangkan sampel anak perempuan pada kelompok usia 11 tahun sebesar 0,78 .

\section{KESIMPULAN DAN SARAN}

Berdasarkan penelitian estimasi usia anak pada etnis Tionghoa yang berusia $6-13$ tahun dengan menggunakan metode Willems dapat diambil kesimpulan sebagai berikut :

1. Estimasi usia anak menggunakan metode Willems dapat diaplikasikan pada populasi etnis Tionghoa.

2. Terdapat perbedaan selisih usia kronologis dengan usia dental antara laki - laki dan perempuan

Penelitian ini memiliki keterbatasan sehingga diperlukan saran untuk perbaikan selanjutnya, yaitu:

1. Diperlukan penelitian lanjutan untuk populasi yang berbeda dengan jumlah sampel yang lebih banyak.

2. Diperlukan penelitian mengenai estimasi usia anak dengan menggunakan metode Willems pada etnis lainnnya di Indonesia

\section{UCAPAN TERIMA KASIH}

1. Prof.Dr.Mieke Sylvia, MAR,drg.,MS.,Sp.Ort, selaku pembimbing utama yang telah menyediakan waktu, tenaga, dan pikiran untuk mengarahkan saya dalam penyusunan Tesis ini. Terima kasih untuk semangatnya.

2. Dr.Haryono Utomo,drg.,Sp.Ort, selaku pembimbing serta yang telah menyediakan waktu, tenaga, dan pikiran untuk mengarahkan saya dalam penyusunan Tesis ini serta mengijinkan 
saya untuk penelitian di tempat praktek beliau. \begin{tabular}{llr} 
3. Dr. & \multicolumn{1}{c}{ Ahmad } & Yudianto, \\
dr.,Sp.F.,M.Kes.,SH, selaku & koordinator
\end{tabular} program studi Ilmu Forensik yang telah banyak membantu selama proses perkuliahan hingga penyusunan Tesis.

4. Adi Hapsoro, drg.,MS, yang telah membantu dalam penghitungan sampel penelitian. Terima kasih atas saransarannya.

5. Para dosen penguji yang telah memberikan saran-saran sehingga Tesis ini dapat terselesaikan dengan baik.

6. Bapak Koeswo Tritjahjono dan Ibu Wiwiek Rinawanti selaku orang tua, adik serta seluruh keluarga yang banyak memberikan dukungan moral dan selalu mendoakan.

7. Suami saya tercinta, Eko Susanto, S.ST. atas segala semangat, dukungan, kesabaran, dan perhatiannya selama ini sehingga saya bisa menyelesaikan studi S2 ini.

8. Putri saya tercinta, Khansa Mayra Fatihah Rusydah yang selalu membuat saya semangat untuk menyelesaikan tesis ini

9. Semua dosen dan $\mathrm{Bu}$ Emmy di Departemen Odontologi Forensik Fakultas Kedokteran Gigi Universitas Airlangga atas bantuan dan pengertiannya selama menyelesaikan penelitian.

10. Sahabat-sahabat saya Icha Artyas,drg, Okky Marita,drg dan Livia Elsa yang telah banyak membantu.

\section{DAFTAR PUSTAKA}

Adams C, Carabott R, Evans S. 2014. Forensic Odontology: An Essential Guide . $1^{\text {st }} \mathrm{ed}$. John

Wiley and Sons, Ltd. p: 138-139.

Almonaitiene R, Balciuniene I, Tutkuviene J. 2010. Factors Influencing Permanent Teeth Eruption. Part one - General Factors. Stomatologija, Baltic Dental and Maxilllofacial Journal. 12: 67-72.

Badan Pusat Statistik. 2010. Data Agregat Sensus Penduduk Tahun 2010 Provinsi Jawa Timur.

Chailet N, Demirjian A. 2004. Dental Maturity in South France : A Comparison Between
Demirjian Method and Poliminial Functions. J Forensic Sci. 49:1-8.

Demirjian A, Goldstein H, Tanner JM. 1973. A New System of Dental Age Assessment. Hum Biol. 45:211-27.

Finn, S.B. 2003. Clinical Pedodontics. Philadelphia: Saunders Company, Inc. 4551.

Handinoto. 2009. Perkembangan Bangunan Etnis Tionghoa di Indonesia. Jakarta

H.M. Liversidge. 2012. The Assesment and Interpretation of Demirjian, Goldstein and Tanner's Dental Maturity. Ann Hum Biol 39(2012) 412-431.

Koentjaraningrat, 2002. Manusia Dan Kebudayaan Di Indonesia. Jakarta : Penerbit : Djambatan, hal. 354

Liem Y. 2000. Prasangka Terhadap Etnis Cina. Jakarta:Djambatan.

Manisha M. Khorate, A.D Dinkar, Junaid Ahmed. 2014. Accuracy of Age Estimation Methods from Orthopantomograph in Forensic Odontology: A Comparative Study. 234:184.e1-184.e8.

M. Maber, H.M. Liversidge, M.P. Hector. 2006. Accuracy of Age Estimationof Radiographic Methods Using Developing Teeth. Forensic Sci. Int. 159 (Supxpl 1) S68-S73

Mc Donald, Avery. 2000. Dentistry for The Child and Adolescent. Missouri: Mosby -Year Book, Inc. 184-214.

Moyers, R. E. 2001. Handbook of Orthodontics. Chicago: Year Book Medical Publisher, Inc. 111-121.

Nelson SJ, Ash MM. 2010. Wheeler's Dental Anatomy, Physiology, and Occlusion. $9^{\text {th }} \mathrm{Ed}$. Elsevier Inc.

Nik-Husein N N, Kai Ming Kee, Peggy Gan. 2010. Validity of Demirjian and Willems Methods for Dental Age Estimation for Malaysian Children Aged 5-15 Years Old. J Forensic Science Internasional. 204:208.e1-208.e6. 
Jurnal Biosains Pascasarjana Vol. 18 (2016) pp

(C) (2016) Sekolah Pascasarjana Universitas Airlangga, Indonesia

Noordjanah A. 2004. Komunitas Tionghoa di Surabaya. Surabaya:Mesiass

Prawestiningtyas E, Algozi AM. 2009. Identifikasi Forensik Berdasarkan Pemeriksaan Primer dan Sekunder Sebagai Penentu Identitas Korban pada Dua Kasus Bencana Massal. Jurnal Kedokteran Brawijaya. Vol XXV. No.2. Agustus 2009.

Peedikayil, Faizal C. 2011. Delayed Tooth Eruption. e-Journal of Dentistry. Vol 1 Issue 4: 81-86.

Proffit, W. R. and H. W. Fields Jr. 1993. Contemporary Ortodontics $2^{\text {nd }}$ Ed. St. Louis:Mosby, Inc

Proffit, W. R. 2000. Contemporary Ortodontics $3^{\text {rd }}$ Ed. St. Louis:Mosby, Inc

Putri A.S, Nehemia B, Soedarsono N. 2013. Prakiraan Usia Individu Melalui Pemeriksaan Gigi Untuk Kepentingan Forensik Kedokteran Gigi. Jurnal PDGI. Vol.62.No.3,September-Desember 2013. Hal 55-63.

Rahardjo, P. 2009. Ortodonti Dasar. Airlangga University Press. Surabaya.

Singh N, Juneja T. 2007. Textbook of Orthodontics. Dalam Basic Principles of Growth. 2nd ed. New Delhi: Jaypee Brothers Medical Publishers.

Suryadinata L. 1981. Dilema Minoritas Cina. Jakarta : PT.Grafiti Pers.

Tan, Mely G.1981. Golongan Etnis Tionghoa di Indonesia. Suatu Masalah Pembinaan Kesatuan Bangsa. Jakarta : PT Gramedia. Hal. 8-9.

Wikipedia. 2015. Kota Surabaya. Available at://id.wikipedia.org/wiki/Kota_Surabaya. Accessed 10 Juli 2015.

Wikipedia. 2016. Indonesia Air Asia Penerbangan 8501. Available at: https://id.wikipedia.org/wiki/Indonesia_Air Asia_Penerbangan_8501. Accesed 25 Juli 2016
Willems G. 2001. A Review of The Most Commonly Used Dental Age Estimation Techniques. J. Forensic Odontostomatol. 19:9-17.

Willems G, Vanolmen A, Spiessens B, Carles C. 2001. Dental Age Estimation in Belgian Children: Demirjian's Technique Revisited. J. Forensic Sci. 46:125-127.

Ye X, Jianng F, Sheng X, Huang H, Shen X. 2014. Dental Age Assesment in $7-14$ years old Chinnese Children: Comparison of Demirjian and Willems Methods. Forensic Science International 244(2014) 36-41. 